\title{
Magnitude of CD8 cell reactivity with a peptide pool is comparable to the sum of responses by individual peptides
}

\author{
Tameem Ansari", Wenji Zhang, loana Moldovan, OLeg Targoni, Ramu A Subbramanian, Paul V Lehmann \\ From Society for Immunotherapy of Cancer 28th Annual Meeting \\ National Harbor, MD, USA. 8-10 November 2013
}

\section{Introduction}

Immune monitoring of $\mathrm{T}$ cell responses increasingly relies on the use of peptide pools. Peptides within the pool that are restricted by the same HLA allele, however, will compete for HLA binding displacing each other. Therefore, how much $\mathrm{T}$ cell reactivity goes undetected when one works with peptide pools?

\section{Methods}

Using a model peptide pool that is comprised of 32 welldefined viral epitopes from Cytomegalovirus, Epstein-Barr virus, and Influenza virus (CEF peptide pool), we assessed peptide competition in PBMC from 43 human subjects. IFN- $\gamma$ was measured using the ImmunoSpot ${ }^{\mathbb{B}}$ Test Kit, and to assure low background, serum-free, CTL-Test ${ }^{\mathrm{TM}}$ Medium was used. The spots were counted using an ImmunoSpot ${ }^{\circledR}$ S6 Core reader.

\section{Results}

The magnitude of the peptide pool-elicited CD8 T cell responses was a mean $79 \%$ and a median $77 \%$ of the sum of the CD8 $\mathrm{T}$ cell responses elicited by the individual peptides. Therefore, while the effect of peptide competition was evident, it was of a relatively minor magnitude. By studying the dose-response curves for individual CEF peptides, we show that several of these peptides are present in the CEF-pool at concentrations that are orders of magnitudes in excess of what is needed for the activation threshold of the CD8 T cells.

\section{Conclusions}

The inhibitory effects due to peptide competition were found to be relatively low for the CEF peptide pool. The presence of $\mathrm{T}$ cells with high affinity for the viral peptides is the reason for this relatively minor competition within the CEF pool.

Published: 7 November 2013

doi:10.1186/2051-1426-1-S1-P94

Cite this article as: Ansari et al:: Magnitude of CD8 cell reactivity with a peptide pool is comparable to the sum of responses by individual peptides. Journal for ImmunoTherapy of Cancer 2013 1(Suppl 1):P94.

R\&D, Cellular Technology Ltd., Shaker Hts., OH, USA

Submit your next manuscript to BioMed Central and take full advantage of:

- Convenient online submission

- Thorough peer review

- No space constraints or color figure charges

- Immediate publication on acceptance

- Inclusion in PubMed, CAS, Scopus and Google Scholar

- Research which is freely available for redistribution 